\title{
It-Based Usury Free Financial Innovations
}

\author{
Bijan Bidabad \\ B.A., M.Sc., Ph.D., Post-Doc. \\ Professor \\ Economics and Chief Islamic Banking Advisor \\ Bank Melli, Iran \\ E-mail:bijan@bidabad.com \\ Mahmoud Allahyarifard \\ Expert of R\&D Dept. \\ Bank Melli Iran \\ E-mail: Allahyarifard@gmail.com
}

\begin{abstract}
Despite development and extension of different ways of financing in financial markets, encompassing Islamic and conventional financing, the mechanism of Electronic Funds Transfer (EFT) of project financing both as borrowed and non-borrowed methods has not been considered at most. Moreover overall IT infrastructures development namely Real Gross Settlement System (RTGS), Automatic Clearing House (ACH), Scriptless Security Settlement System (SSSS) and International Bank Account Number (IBAN) for authentication process and the international meta bank network of Single Euro Payment Area (SEPA) and also international integrated banking networks including the Society For Worldwide Interbank Financial Telecommunication (SWIFT) and Interbank Information Transfer Network (Shetab), and other accomplished endeavors are not efficient in absorbing international contributions for project financing through foreign exchange funds in the different countries, satisfactory E-Payment mechanism in informative portal systems for investment projects are weak. In this way, the role of applying E-Payment systems for attracting foreign investment through retail resources mobilization and design of financial instruments with the capability of transacting in the secondary markets should be reconsidered. In this paper by having a glance at different types of investment project financing, we introduce a new project financing mechanism based on E-Payment with non-usury financial instruments to complete investment project financing chain in the form of Rastin Profit and Loss Sharing (PLS) banking.Sharia compliance of financing instruments in one side and accessibility in absorbing international retail fore ign exchange sources on other side are two fundamental discussible items in this paper. In this way by designing a new system of "Non-Usury Scriptless Security Settlement System" (NSSSS) with non-usury mechanisms -avoiding legislative (Sharia) circumvention- can provide the two cited goals in designing non-usury financing instruments through IT-based non-usury financial innovations which includes of Rastin Certificates in Rastin PLS banking, and Non-Usury Bonds namely Rastin Swap Bonds.
\end{abstract}

Keywords: Rastin Banking, E-Payment, RTGS, ACH, NSSSS, PLS, SSSS.

\section{Introduction}

Definitely, investment is a reliable method for accelerating economic growth and employment and could be applied as an accelerator for speeding up economic growth and development. The foreign investment will be able to improve management systems, exchange of the economic experiments, and importation, and applying of new technology. Traditional financing methods for importation and injection of capital to investment projects do not suffice with respect to information and communication technology (ICT) progresses and development of international financial networking. The extending number of countries as members of the World Trade Organization (WTO) and tariff reduction policy, freedom of capital inflow and 
outflow based on capital rate of return are some significant reasons for existing hard competency over the products of the investment project at global markets. In this way, the significant endeavor of the entrepreneurs of the investment projects is to how finance and to reduce mark-up prices of the products and services. The Sharia-based financial instruments in investment project financing and the theosophy of usury prohibition for stability and health of the financial and other related real economy markets are some main reasons of the enthusiastic attraction of the non-usury financial innovations with known characteristics. ${ }^{\mathrm{I}}$ On the other hand, increasing the volume of transactions obliges to trace financial transactions, the reality of transactions and avoiding from any circumvention, increasing speed, accuracy and decreasing of the mark-up prices and increasing financial efficiency are some main reasons for necessary role of information technology (IT) in Islamic financial markets.

In conventional financing approaches, either local or global, some instruments are used. Namely: local credit facilities, foreign exchange credit facilities, foreign exchange reserve fund, Musharakah papers, convertible partnership bonds, specific long term investment deposit certificate, securitization and Sukuk for local financing and foreign exchange bonds, foreign resources finance from foreign banks, foreign direct investment, Public-Private partnership (PPP), buyback contracts, financing from international institutions of World Bank and development banks and export credit agencies (ECAs) ${ }^{2}$ are used for foreign financing.

The investment project financing is performed as the borrowed method, namely: finance, refinance, usance, security and etc. and non-borrowed as a civil partnership and direct investment that we are discussing here. Then we are going to introduce some IT based new non-usury financial innovations.

\section{Borrowed Financing}

In the borrowed financing method, the principle and interest of the resources are guaranteed by the government. The borrowed financing encompasses the whole sorts of short term, middle term and long term credit lines in form of finance and refinance loans which are provided by international banks, non-banking financial and monetary institutions, World Bank (WB), development and regional banks namely Islamic Development Bank (IDB) and other financial institutions and even governments. Issuance of the foreign exchange securities and Musharakah papers are classified in borrowed financing category - in case of the government guarantee of both principal and interest. In this method, buyers of bonds are not confronted with any risks and the paying back the principle, and interest in this kind of debt based financing is an obligation for the issuer of the bonds (government). The traditional financing methods in Iran are as follows:

\section{Securities or Musharakah Papers}

In Iran, non-usury financing instruments in the form of Musharakah bonds (RLS) has been issued and taken into consideration in 1995 for the first time. Lack of IT-based supervision mechanism and lack of its development around the world are some constraints to this kind of financing approach. Iran's foreign exchange bonds issuance for foreign countries, first time returns to early 2000. Legal prohibition of the government to borrow from banking systems in order to make the balance of her budget according to the context of 2002 annual budget law and also looking for diversified financing aim and being present at global financial markets were some reasons for issuance of foreign exchange bonds in Iran.

\section{Certificate of Deposit (CD)}

Certificate of Deposit as public or specific deposits is known as other financing instruments. The financing through CD was approved by the Central Bank of Iran (CBI) in 200I to encourage investors to make short term deposit with transaction capability in secondary markets. Undeveloped secondary market with IT-based mechanisms and also lack of required cultural and organizational development non-publicity requirements are some main reasons for not forming the secondary markets for this kind of securities. The foreign exchange CD also was considered on the basis of the CBI's back up in 2007 a foreign exchange financing instrument for absorbing the international resources particularly of Iranians resident at foreign countries at a global financial crisis.

\section{Non-Borrowed Financing}

Non-Borrowed financing includes those foreign resources that principle and interest return and risk of the investment are to be transferred to investors, and the government has no commitments against any parties. Acceptance of the whole risks by the investor, nom-increasing government commitments, application of new technology, managing improvement are some efficiency

\footnotetext{
I See:

http://bidabad.com/doc/pls-business-cycles.pdf ${ }^{2}$ The Development Banks and Export Credit Agencies (ECAs) are private or semi-governmental institutions that are intermediates between government and exporters in export financing and can be as partner in financing, insurance and guarantee of project. 
characteristics of the non-borrowed financing. Although non-borrowed financing follows the debt market position since the financial resource provider has participated with both profit and risk of investment, so it complies with non-usury transactions characteristics and as a result the Islamic countries interested in applying this method to finance the projects.

Generally, different types of non-borrowed financing methods in different Islamic countries are as follows:

$\underline{\text { Sukuk }}$

Debt markets are an inseparable part of the financial sector, but due to Riba (usury) prohibition according to the jurisprudence of Islam, the countries that are looking for applying non-usury transactions to meet their financial needs have planned to develop substitute financial instruments for debt market complying with non-usuric transactions criteria. In result, the last recent years, the Islamic debt based bonds, namely Sukuk has had significant growth, and plenty of them was issued by corporations and governments around the world. Based on AAOIFI standards (2004), over I4 types of Sukuk have been recognized and introduced recently. The most popular types of Sukuk are Ijarah Sukuk (in assets), Estesna Sukuk (in projects), Murabaha Sukuk (in ownership cases in debt), Musharakah Sukuk (in trade) and Estesmar Sukuk (in investment). Some of this type of Islamic bonds has been issued in huge volumes by some Islamic countries and organizations, namely Malaysia, Bahrain, Dubai, Pakistan, IDB and etc. Marketability of these bonds in the secondary market depends on quality evaluation processes of the assets and existing IT-based and e-payments transacting infrastructure. The Sukuk issuance with marketable capabilities has been considered across stock markets of the Islamic country markets.

The significant point of Sukuk issuance is that in spite of the prohibition of usury, in calculating profit the usury mechanism is used and the rate of return of this asset is the same as fixed interest rates of LIBOR plus risk premium or similar margins that somehow instills usury-doubt into mind.

\section{The Islamic Zero Coupon Bond}

This kind of bonds has not any coupon for paying profit during the investment period from issuance time up to maturity, and the issuance is based on discount mechanism and is popular in Malaysia. Although up to maturity, no profit is paid the rate of return of these securities can be calculated through the difference of the par value and discounted price. The Islamic zero coupon security is conducted on the basis of the transaction contract (Bai' Contract), and it is transacted on credit, then cash with discounting. This transaction is a kind of circumvention and enters to usury realm as some jurists protest.

\section{Direct Investment}

Direct investment is another project financing method based on foreign exchange resources. In Iran, The Organization for Investment and Economic \& Technical Assistance set up internet-based database software which brought the information from the government and private corporations projects proposed to this organization in a separate collection to encourage foreign investors and financiers. Therefore, the foreign financers or investors can make the decision on each project profile through this Internet-based portal, and it is possible to choose any project for financing or participate through them. This endeavor is just informative, and e-payment and financing processes through the foreign retail funds are not engaged in. Lack of available financial instruments with convenient processes and marketable bonds transaction mechanism in primary and secondary markets based on information technology are of extant constraints alongside the projects financing through the foreign exchange resources in Iran.

\section{Indirect Investment}

The different types of indirect investment for investment project financing considering the type of contracts are buyback, publicprivate partnership (PPP) and civil partnership as follows:

Buyback

In manufacturing projects, finance of construction and equipping processes of enterprises could be conducted through Buyback contracts. That is the buyer of machines and technology prepares required resources through pre-sales of the future goods and services to the producer of the equipment instead. In buyback contract, the entrepreneur of the projects make an agreement with financers on pre-sales of produced goods and services instead of a refund and will pay back the money in a particular duration with determined prices. This approach, due to preventing foreign exchange outflow from the country and preserving the balance of payment (BOP) position is attractive for the governments.

Public-Private Partnership (PPP)

Public-Private Partnership (PPP) is an important financing method for infrastructural projects. In this method, the whole processes of design, construction, financing, and operation entirely are considered. The government donates the privilege of the operation of the project to the concessionaire for the duration. The concessionaire can be a corporation or consortiums of the corporation. The required guaranty and refund for this kind of financing will be based on the cash flow of the project outcomes. This type of financing entails Limited-Recourse or Non-Recourse rights to the government. 
Civil Partnership (Musharekate Madani)

According to the non-usury banking law - approved in 1982- civil partnership is defined as "to merge cash or non-cash capitals that belong to different private or legal entities to get profit jointly complied with the contract". On the other words, Musharekate Madani is a contract that two or more persons who have a bilateral or multilateral agreement join their capitals for running a particular business to gain profit. In this financing, the bank is as a financer, and the entrepreneur is her counterpart, and the partners gain some proportions according to their shares.

\section{It Infrastructure Requirements}

The payment process is a significant pillar for initiating and fulfillment of all commercial transactions among buyers and sellers. Development and extending different types of e-commerce -particularly business to consumer (B2C) and business to business (B2B)- is appropriate infrastructure for transactions of different asset-based securities (ABS) either as Sharia complied or conventional transactions. So it is necessary to review required information technology infrastructure before spelling out IT based non-usury financial instruments transaction mechanisms in investment project financing. Generally, prerequisites and infrastructures for initiating the transactions at the primary and secondary markets are as follows:

\section{Electronic Fund Transfer (EFT)}

\section{Automated Clearing House $(\mathrm{ACH})$}

Automated clearing house $(\mathrm{ACH})$ is a system implemented for retail payment and whole interbank transferring processes in huge volume automatically. Transactions settlements in this system are done by batch at a scheduled time (usually at 24 O'clock). The members' banks can issue direct credit transactions ${ }^{3}$ or direct debit transactions ${ }^{4}$ by submitting a batch file which contains different transactions order to the counterparty bank. In this system, the creditor or debtor accounts of the customers are transferred on the basis of International Bank Account Number (IBAN).

Real Gross Settlement System (RTGS)

The real gross settlement system (RTGS) is a system for payment and transferring high and time-based payments. The central banks mostly are the owner of this system. For transferring of money, it isn't compulsory to have an account in destination bank, and it is just enough to have an account in remittance bank for funds transfer. The RTGS is a non-cash transferring system.

Scriptless Security Settlement System (SSSS)

This system is designed for banks' liquidity management and transacting short term assets as securities, derivatives like futures and options to provide required liquidity. Adding and saving of the records of the securities owners, transferring the ownership, transacting and repurchasing securities and bonds, authentication of securities owners, issuance of paperless digital securities in an integrated information system are some of the functionalities of this system. Paying and withdrawing funds for the transaction of securities are done through RTGS. The banks at most, to prepare required liquidity, sell their bonds to the central bank at the early hours of working time and then repurchase the bonds in case of redundant funds automatically through the RTGS that is held beside the central bank.

\section{Authentication Mechanism}

International Bank Account Number (IBAN)

IBAN is an identifier that defines a unique specific banking account number over the world. This identifier is compatible with the international standard of ISO I36I6:2007. IBAN creates equal banking account number identification across the world for simplifying interbank transactions.

Basic Bank Account Number (BBAN)

BBAN is just the same ordinary customer account number. In other words, this identifier is an exclusive account number that specifies a specific account across a unique bank. In applying ACH, it is necessary to transfer the account number of payer and payee across the banks on IBAN. So, up to spreading IBAN among the customers, it is not compulsory to know both own and payee account numbers on IBAN basis, but they will be able to use the services of this system through BBAN or generating the IBAN through the website of the customer's bank.

\footnotetext{
${ }^{3}$ This is a payment method that the account holder permits the bank to withdraw the corresponding amounts from the owner's accounts in particular times then to credit other specific account in other banks.

${ }^{4}$ It is a kind of funds transferring that account holder permits the bank to withdraw the considered amounts in particular times from other accounts in different banks and then credit them into the account number of the customer. Performing this conduction depends on the multilateral agreements between debtors and creditors.
} 


\section{Electronic Funds Transfer (EFT) Experiences}

The Society for Worldwide Interbank Financial Telecommunication (SWIFT)

The SWIFT electronic fund transfer in Iranian banks is done in this way that the remitting bank after tracing the bank of the beneficiary and her SWIFT number transfers the amount through the subsidiary branch or agent of the bank. In case of lack of subsidiaries or agents banks over the world, the transferring process is done through other agents that have a subsidiary or a second agent in the beneficiary's bank country. The high commission in this case in the beneficiary's bank country and then long duration remittance process are weak points of this kind of electronic fund transfer in Iran. The authentication process would be possible in case of having a SWIFT number.

Interbank Information Transfer Network

This network is known as Interbank Switch Center, and it is called Shetab in Iran. This center has been running since the end of I99I. The card services center connects the whole Iranian banks, including government and private banks and even non-bank financial institutions, and this network prepares authentication possibility for customers who want to transfer or pay. The cardholder of every member bank can utilize e-banking services and products of the other banks and non-banking financial institutions. Hence the whole automatic teller machines (ATM) and the EFTPOS devices of Shetab member banks which connected to this center can offer the services to the customers of the other banks. In addition, it decreases the investment costs, and subsequently, the required expenditures of banks provide extensive services for customers.

Arab Payments and Securities Settlement Initiative (API)

World Bank in co-operation with the Arab Monetary Fund and Regional and International Organizations established the Arab Payments and Securities Settlement Initiative (API). This organization encompasses 22 countries who are members of the International Arab Fund and established with the purpose of evaluating and strengthening of the payment systems among Arab countries to improve soundness, efficiency, integrity and creating long term organizational capacity in the region for supporting the development of security settlement and reimbursement systems.

Paypal

Paypal is a global and secure payment method known as peer to peer (P2P) system. This kind of global payment possesses the following advantages:

- Merchants pay low fees; individuals pay nothing

- Interest paid on deposits

- Mass (bulk) payment is possible

- Business model: fees + float

- FDIC $^{5}$ pass-through insurance - Against bankruptcy of Paypal

- Different protection for fraud

- Mobile payments support

- Penetration in USD, CAD, GBP, EUR, JPY, AUS

- $\quad$ B2C and B2B support

5. Non-Usury Scriptless Security Settlement System (Nssss)

This system is considered for the transaction of Rastin Certificates at the Rastin Profit and Loss Sharing (PLS) banking system and the other Non-usury financial innovations along with Rastin PLS banking namely, Rastin Swap Bonds and other Islamic Securities. The significant difference between NSSSS and SSSS is in securities transaction mechanism. Somehow the transactions and processes of securities settlement at the NSSSS are based on usury-free transactions, while the Scriptless Security Settlement System (SSSS) is based on conventional usury transactions mechanism. A model of this system is developed by the Bank Melli Iran titled by Profit and Loss Sharing Banking System and will be operational in the near future and is in the stage of computer program coding ${ }^{6}$. Generally, the specifications and capabilities of this system are as follows:

- Performing E-payment processes through the Banks' cards of the Shetab network or through reputable global cards namely VISA, Master and American Express (needs necessary agreements and connectivity to the card's ports of the e-

\footnotetext{
${ }^{5}$ Federal Deposit Insurance Corporation (FDIC)

${ }^{6}$ This system is supervised and controlled by the PLS expert committee of Bank Melli Iran and is designing by Sadad Co. For more information see the following links: http://89.235.64.I38/Fa/FirstPage.aspx http://89.235.64.138/PLSManagerPanel/Loginpage.aspx
} 
payment service providers).

- Multi-currency support

- Multi-language support

- SWIFT connectivity and connect to other e-payment service providers switch namely PayPal (needs necessary agreements with cards issuer and EFT service providers as well)

- Applying ACH for retail payments and RTGS for bulk payments using IBAN and other integrated authentication facilities. ${ }^{7}$

- Publicity and designing different e-shelving rack for offering Islamic securities

- Buyer and seller queues and offered prices monitoring

- To dispose of the auction and doing a final transaction of Non-usury bonds based on competitive prices

- Automatic refund and pay back after quitting the auction at the end of auction schedule or before the auction and admitting the offered upward prices for retake part for the new auction.

- Compatible with the other financial systems and subsystems and integrity with core banking.

- Accounting operations, input data records, customer desktop monitoring, record and processes tracing, accounting, and auditing.

- Management reports and decision support system (DSS) for different management, experts, and customers levels and request by a parametric report generator system.

- Comparison of different business opportunities in view of expected profit, maturity date, capability, and capacity of the entrepreneurs and other effective specifications of risks and returns.

- Systematic risk management including liquidity, credit, operation and market risk

- Designing bulk and basket for defined financial certificates.

- Analytical and fundamental analysis features and financial engineering.

- Coding of the certificates based on international standards.

Transactions in this system are based on some of the non-usury financial innovations as follows:

\section{IT-Based Non-Usury Financial Innovations in NSSSS}

The IT role in the fulfillment of non-usury financial innovations is inevitable ${ }^{8}$. In other words, IT infrastructures in different dimensions, namely ACH, RTGS, NSSSS, and IBAN, give rise to the development of the markets of this kind for Islamic financial innovations. Generally, the designed Non-usury financial innovations are divided into the following categories as follows:

\section{Rastin Certificates}

Rastin Certificates are a collection of designed certificates in Rastin PLS Banking Base system and its financial subsystems. These certificates can be anonymous or named papers, which are transferable and negotiable online through the website of the bank and are issued with a nominal price and for a certain period. The owners of these certificates share the results of the project proportional to nominal price and participation period of the certificate.

Various Rastin Certificates and their characteristics according to the kind of participation in the PLS Base system or its financial subsystems regarding the type of project and the asset used as:

- $\quad$ PLS Base: Musharakah (Participation) and Pazireh (Subscripted) Certificates.

- IFS: Future Certificate. ${ }^{10}$

\footnotetext{
${ }^{7}$ The integrated authentication system is compiling at the Organization and Skills Department of Bank Melli Iran under supervision of the Rastin PLS banking experts.

${ }^{8}$ For more information see:

Bidabad, Bijan and Mahmoud Allahyarifard, "Implementing IT to fulfill the profit and loss sharing mechanism", Islamic Finance News (IFN) Journals, Vol. 3, Issue 3, $6^{\text {th }}$ February 2006. http://bidabad.com/doc/summery-pls-it-I.pdf

Bidabad, Bijan and Mahmoud Allahyarifard, "IT role in fulfillment of profit and loss sharing", Proceeding of The $3^{\text {rd }}$ International Islamic Banking and Finance Conference, Monash University, Kuala Lumpur, Malaysia, $16^{\text {th }}$ and $17^{\text {th }}$ November 2005. http://www.bidabad.com/doc/english-pls-5.pdf

${ }^{9}$ Bidabad, Bijan, Rastin Profit and Loss Sharing (PLS) Base System, 2012. http://www.bidabad.com/doc/pls-base-en.pdf

${ }^{10}$ Joalah Financial Sharing (JFS): is a method in which, bank finances entrepreneur (producer) from depositor's resources or the provided sources by buyer.

Bidabad, Bijan, Joalah Finance Sharing (JFS), 20II. http://www.bidabad.com/doc/jfs-paper-en.pdf
} 
- $\quad$ MFS: Mudarabah and Periodic Mudarabah Certificates. ${ }^{\text {II }}$

- IFS: Ordinary Mughasatah (installment), Rental Mughasatah, and Musharakah Mughasatah Certificates. ${ }^{12}$

- $\quad$ RFS: Mortgage Sharing, Periodic Mortgage Sharing, Mortgage Mudarabah (commerce), Periodic Mortgage Mudarabah, Mortgage Muzaraah (cultivating), Periodic Muzaraah, Mortgage Mugharasah (planting), Periodic Mortgage Mugharasah, Mortgage Musaghah (irrigation), Periodic Mortgage Musaghah, Mortgage Istisna (industrial/manufacturing), Periodic Mortgage Istisna and Rental Certificates. ${ }^{13}$

- $\quad$ BFS: Bail Certificate. ${ }^{\mathrm{I}}$

- $\quad$ RPS: Social Security, Personal Security, and Pension Security Certificates. ${ }^{15}$

- $\quad$ RST: Takaful and Loan Certificates. ${ }^{16}$

Project Financing through Rastin Certificates: The Rastin Profit and Loss Sharing (PLS) financial instruments titled by Rastin Certificates and also the IT-based prepared opportunities by IT subsystem namely NSSSS anywhere and anytime will absorb foreign capital for investing on different Musharakah projects. Value-added creation, encouragement of creativity and innovation for running new projects, investment return based on real economy sector, no need to primary accomplished assets for issuance of the Rastin Certificates, anonym Rastin Certificates and transacting capability across the world and marketability of this kind of certificates before accomplishing the investment project are some specifications of this new financial innovation. ICT and web-based services implementation for the purpose of tracing digital inflows and outflows of cash in form of multi-currencies funds for issuance of foreign exchange or local currency based Rastin Certificates and coordination with e-payment service providers all over the world are some solutions for going out from existing challenges of the project financing in both traditional usury-free and usury-bearing financing methods. By applying the new IT-based systems namely, the investors (depositors) authentication and recognition system amid them IBAN and designing of e-payment services as same capabilities as PayPal in the internet based secondary market portal in Rastin PLS banking can afford to apply and absorb retail foreign exchange funds across the world for the purpose of the introduced projects financing. This solution makes customer free from having a local account number whether in the operator bank or the whole set of banks that are members of the Shetab network. In case of physical transferring of foreign exchange funds, it is possible to employ the ACH or $\mathrm{RTGS}^{17}$ services as well. Although in the short term due to the imposition of global sanctions against Iran it is not possible to have necessary agreements with e-payment service providers namely $\mathrm{Pay} P a l$ so in this respect, the IT-based environment can be prepared by the defined mechanism, and it is possible to participate in investment projects all over the world. Transacting of the securities through NSSSS is based on competitive price, and securities owners

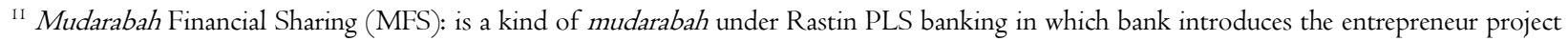
proposal in the field of trade or transaction of commodities (commerce) to depositors.

Bidabad, Bijan, Mudarabah Financial Sharing (MFS). 20I1. http://www.bidabad.com/doc/mfs-paper-en.pdf

${ }^{12}$ Installment Financial Sharing (IFS): in IFS, installer (depositor) will finance a portion of the needed fund of entrepreneur through the bank for a certain period of time (amortization period). The entrepreneur will pay back his share by installments and will own the total property of the project and IFS ends.

Bidabad, Bijan, Installment Financial Sharing (IFS), 20I I. http://www.bidabad.com/doc/ifs-paper-en.pdf

${ }^{13}$ Rent Financial Sharing (RFS): entrepreneur temporarily donates the ownership of a part of his productive asset (assets of an operating firm), rental asset (those assets, which can be let) or dead asset (non-operating or suspended firms or uncultivated lands assets) to depositor who finances him but keeps it as mortgage. Then pays back the fund received from the yields of the asset proportional to depositor's share to depositor at the end of contract, or periodically. The original deposit of depositor will be given back to him after the end of project. The profit of the project will be given to depositor periodically or in a lump.

Bidabad, Bijan, Rent Financial Sharing (RFS), 2012. http://www.bidabad.com/doc/rfs-paper-en.pdf

${ }^{14}$ Bail Financial Sharing (BFS): is the application of deposit of depositor by entrepreneur to produce a defined commodity and delivering the commodity or paying back its value in future specific time.

Bidabad, Bijan, Bail Financial Sharing (BFS), 2012. http://www.bidabad.com/doc/bfs-paper-en.pdf

${ }^{15}$ Rastin Personal Security (RPS): to create competitive conditions and to increase the efficiency of social security insurance and diminishing antitrust of social security systems and pension funds, private and public pension funds are established according to Rastin Banking regulations. People and firms can allocate a portion of their obligatory (or optional) insurance premium payments (for himself or his employees) for social security to the funds that operate under Rastin Personal Security (RPS) and enjoy its benefits. Therefore, they will be exempted from obligatory insurance premium payments equal to the payment they have paid to these funds.

Bidabad, Bijan, Rastin Personal Security (RPS), 2012. http://www.bidabad.com/doc/rps-paper-en.pdf

${ }^{16}$ Rastin Social Takaful (RST): benevolent people can deposit their funds at banks for charity purposes, and bank will be allowed to pay profit (or the principal as well) of deposit to needy people, in form of loan or non-returnable payments (according to the depositor request). Bidabad, Bijan, Rastin Social Takaful (RST), 2012. http://www.bidabad.com/doc/rst-paper-en.pdf

${ }^{17}$ For more information see: Bidabad, Bijan and Mahmoud Allahyarifard, "IT Role in Fulfillment of PLS Mechanism (Islamic Banking)", New Economics and Trade Journal, No 3,Winter 2005, pp 1-37. http://bidabad.com/doc/english-pls-5.pdf http://prd.moc.gov.ir/jnec/farsi/3rd/Article2.pdf
} 
(suppliers) and buyers (demanders) can offer competitive prices until auction time. The par value of this certificate is equal to the first time offer in the primary market, and up to the maturity, there will not be any payment as a predetermined profit to the certificates' holders. ${ }^{18}$

\section{Rastin Swap Bond (RSB)}

Rastin Swap Bond (RSB) is based upon Mubadala (swap) contract between Mobadil (swapper) and Motebadil (swapee) in which the durations and substances of swaps are equal for first and second swaps. Motebadil (swapee) issues the bond and owes to Mobadil equal to the nominal value of the bond, and should pay this amount (badal) to Mobadil (swapper) at maturity. The issuer (Motebadil) is obliged to give the mobaadal for the same amount and period as badal to mobadil. He can choose a combination of amount and period that the multiplication of amount by the period of mobaddal be equal to that of badal. At second maturity, mobadil is committed to returning mobaddal to motebadil.

No interest rate is involved in these bonds, and they are of four kinds: Central Bank Rastin Swap Bond, Treasury Rastin Swap Bond, Bank Rastin Swap Bond, and Commercial Rastin Swap Bond. They can be in domestic money or foreign exchange. ${ }^{19}$

Usury doubt of bonds in conventional banking is the main reason for less development of Islamic financial markets. By this new financial innovation, Non-usury Bonds are designed and issued. Rastin Swap Bond (RSB) will be issued in par value and can be transacted through NSSSS. The market transaction of these bonds is based on auction, which is done by implementing the IT based system. Riba prohibition is a substantial reason for eliminating conventional treasury bonds from monetary policy instruments in Iran. IT role with defined mechanisms in the Non-usury scriptless securities settlement system (NSSSS) and with respect to defined transacting mechanism would revive treasury bonds with non-usury specification and be known as significant monetary instruments improvement. ${ }^{20}$

For implementing Non-Usury Scriptless Security Settlement System (NSSSS), Central bank establishes the integrated Usury-free Scriptless Security Settlement System with specific characteristics and capabilities and activates the registration portal for entrepreneurs of Rastin PLS banking. Compliance with Sharia is the necessary condition for the entrance of financial documents and instruments in this portal.

Portals of Rastin Certificate Markets (RCM) of banks are to be designed in accordance with central bank's standards so that the information concerning financing projects through Rastin PLS banking, entrepreneurs and Rastin Certificates will be updated online in NSSSS system. This system should be capable of online updating of information concerning Rastin Certificates and Rastin Swap Bonds of bank's portal for each transaction, settlement, capitalization or any other kinds of transaction and transition of Rastin Certificates and Bond by registering them in the system.

\footnotetext{
${ }^{18}$ For more information see:

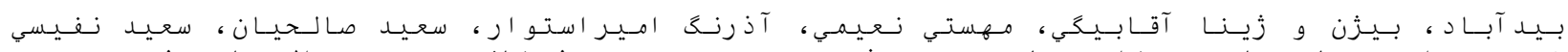

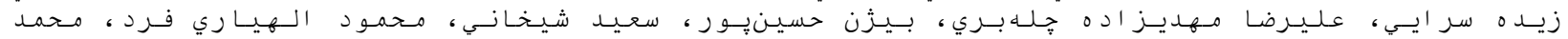

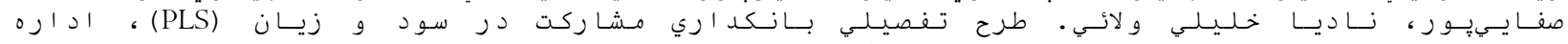

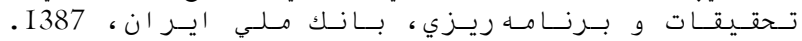

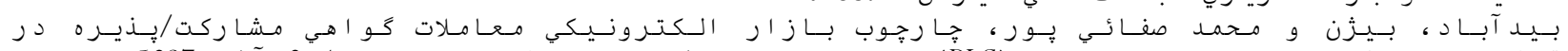

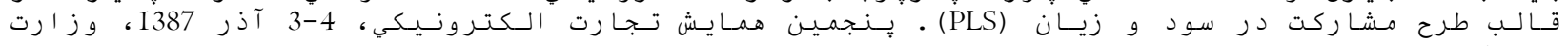
http://www.ecommerce.gov.ir/EArchive/EArchiveF/Item.asp?ParentID=438ItemID=I82

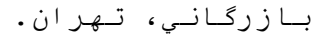

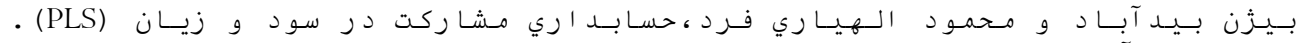

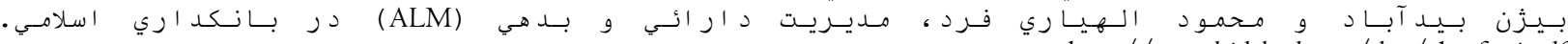
http://www.bidabad.com/doc/alm-farsi.pdf

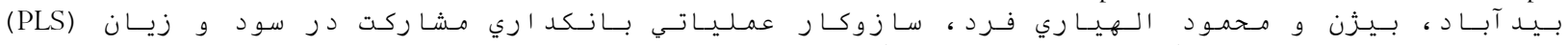

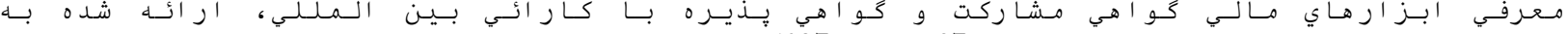

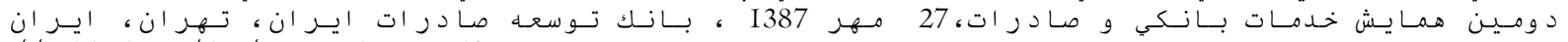
http://bidabad.com/doc/PLS-Banking-7.pdf

http://bidabad.com/doc/PLS-Banking-Export-Deveopment-Bank-2.ppt

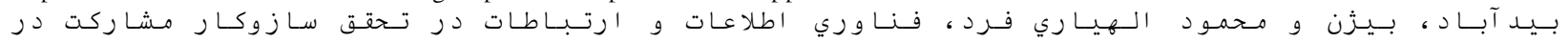

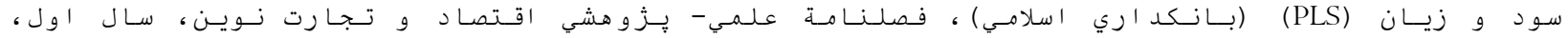

http://www.bidabad.com/doc/pls- it-2

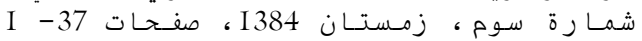
http://prd.moc.gov.ir/jnec/farsi/3rd/Article2.pdf http://bidabad.com/doc/Pls_it-fa.pdf

${ }^{19}$ Bidabad, Bijan, Abul Hassan, Ben Ali Mohamed Sami, Mahmoud Allahyarifard. Interest-Free Bonds and Central Banking Monetary Instruments. International Journal of Economics and Finance. Vol. 3, no. 3, August 20II, pp.234-24I.

http://www.ccsenet.org/journal/index.php/ijef/article/download/II665/8300

${ }^{20}$ Bidabad, Bijan, Mahmoud Allahyarifard, Mahnaz Rabiei, "Non-Usury Bonds", Forthcoming. 


\section{Conclusions and Policy Recommendations}

Despite throughout extending Islamic financial markets, particularly in Malaysia, the current transacting practices and mechanisms of Islamic financing instruments are protested by some jurists and Islamic economists. By scrutinizing the transacting process of Islamic securities, usury signs can be found in them easily. Amid the investment project financing procedures, whatever compatible with non-usury transactions are known as non-borrowed financing approach. For participating of financer in driven risk and return of investment and for applying the debt-equity mobilization beyond the borders due to the scarcity of this significant investment factor, development of IT infrastructures with giving priority to the theosophy of us ury prohibition is inevitable. Hence, actualizing of transactions while avoiding from any circumvention and also extending and development of Islamic financial markets entail implementing IT-based infrastructures, which encompasses ACH, RTGS, NSSSS, and IBAN and also development of Meta banks, integrated and global networks namely SEPA, SWIFT, SHETAB and accomplished endeavors for absorbing global participation to project financing through foreign exchange funds. Sharia compliance-based transactions of financing instruments on one hand and accessibility to global retail foreign exchange funds on another hand will be two fundamental factors in the recent Islamic financial instruments innovations. In this way, by designing a new system of NSSSS with non-usury transactions mechanism, it is possible to avoid from any circumventions by implementing new It-based non-usury financial innovations including Rastin Certificates in Rastin PLS banking, and Non-Usury Bonds namely Rastin Swap Bond (RSB) for liquidity financing and monetary policies.

\section{References}

Bidabad, Bijan. (2014). New Operational Islamic Banking System, Volume One, Theoretical Foundations, LAP Lambert Academic Publishing, OmniScriptum GmbH \& Co. KG, ISBN: 978-3-659-54463-7.

Bidabad, Bijan. (20I4). New Operational Islamic Banking System, Volume Two, Applicational Issues, LAP Lambert Academic Publishing, OmniScriptum GmbH \& Co. KG, ISBN: 978-3-659-552I0-6.

Bidabad, Bijan (2018), General Regulatory Framework in Rastin Profit and Loss Sharing Banking (Part I-Operational Context). Journal of Business and Finance in Emerging Markets, JBFEM, [S.1.], v. I, n. I, p. I I -26, May. ISSN 2580-5568. https://doi.org/I0.32770/jbfem.volI I I-26

http://www.bidabad.com/doc/rastin-regulatory-en-I.pdf

Bidabad, Bijan (2018), General Regulatory Framework in Rastin Profit and Loss Sharing Banking (Part II-Legal Groundwork). Journal of Business and Finance in Emerging Markets, JBFEM, JBFEM, [S.1.], v. I, n. 2, p. I09-I26, Nov. ISSN 25805568.

https://doi.org/I0.32770/jbfem.volI I09-126

http://www.bidabad.com/doc/rastin-regulatory-en-II.pdf

Bidabad, Bijan (2019), General Regulatory Framework in Rastin Profit and Loss Sharing Banking (Part III-Auxiliary Provisions). Journal of Business and Finance in Emerging Markets, JBFEM, May, Vol 2, No. I, pp. 5I -65. ISSN 25805568.

https://doi.org/I0.32770/jbfem.vol25I-66

http://www.bidabad.com/doc/rastin-regulatory-en-III.pdf

Bidabad, Bijan and Mahmoud Allahyarifard, "Implementing IT to fulfill the profit and loss sharing mechanism", Islamic Finance News (IFN) Journals, Vol. 3, Issue 3, 6th February 2006. http://bidabad.com/doc/summery-pls-it-I.pdf

Bijan Bidabad, Mahmoud Allahyarifard. IT role in fulfillment of Profit \& Loss Sharing (PLS) mechanism. Proceeding of the 3rd International Islamic Banking and Finance Conference, The Monash University, KL, Malaysia, I6-I7 November, 2005. International Journal of Islamic Banking and Finance Research, 3(2), 44-59, 2019.

https://www.cribfb.com/journal/index.php/ijibfr/article/view/274

http://www.bidabad.com/doc/english-pls-5.pdf

http://www.bidabad.com/doc/pls-it-en.ppt

Bijan Bidabad, Mahmoud Allahyarifard. Assets and Liabilities Management in Islamic Banking. Proceeding of the 3rd International Conference on Islamic banking and Finance, Risk Management, Regulation and Supervision, Bidakara, Jakarta, Indonesia, 23-26 February, 2010. pp. 396-4I3. International Journal of Islamic Banking and Finance Research, 3(2), 32-43, 2019. 
https://www.cribfb.com/journal/index.php/ijibfr/article/view/272

http://www.bidabad.com/doc/alm-english.pdf

Bijan Bidabad, Rastin Certificate Market (RCM), Complementary System of Rastin Banking, 20I3. International Journal of Islamic Business \& Management, 3(I), 35-43, 2019.

https://www.cribfb.com/journal/index.php/ijibm/article/view/260

http://www.bidabad.com/doc/rastin-bank-rcm-en.pdf

Bidabad, Bijan, Abul Hassan, Ben Ali Mohamed Sami, Mahmoud Allahyarifard (20I I) Interest-Free Bonds and Central Banking Monetary Instruments. International Journal of Business and Management Science. Vol. 3, no. 3, August.

Bidabad, Bijan, Rastin Profit and Loss Sharing (PLS) Base System. Journal of Islamic Economics, Banking and Finance, pp. 32 57, Vol. 9 No. 4, Oct - Dec 2013.

http://ibtra.com/pdf/journal/v9_n4_article2.pdf

http://www.bidabad.com/doc/pls-base-en.pdf

Bidabad, Bijan, Joalah Finance Sharing (JFS). Journal of Islamic Economics, Banking and Finance, Volume-I2, No. I, JanuaryMarch, 2016, pp. 33-48.

http://www.bidabad.com/doc/jfs-paper-en.pdf

http://ibtra.com/pdf/journal/vI2_nI_article2.pdf

Bidabad, Bijan, Mudarebah Financial Sharing (MFS). Journal of Islamic Economics, Banking and Finance, JIEBF, Volume - I0, Number - I, January - April 20I4, pp. 56-68.

http://www.bidabad.com/doc/mfs-paper-en.pdf

http://ibtra.com/pdf/journal/vIO_nI_article3.pdf

Bidabad, Bijan, Installment Financial Sharing (IFS): A Financial Subsystem of Rastin PLS Banking. International Journal of Islamic Banking and Finance Research, 3(I), 28-42, 2019 .

https://www.cribfb.com/journal/index.php/ijibfr/article/view/267

http://www.bidabad.com/doc/ifs-paper-en.pdf

Bidabad, Bijan, Rent Financial Sharing (RFS). Journal of Islamic Economics, Banking and Finance, Vol. I0 No. 2, pp.: 38-53, April-June 20I4.

http://www.bidabad.com/doc/rfs-paper-en.pdf

http://ibtra.com/pdf/journal/vIO_n2_article2.pdf

Bidabad, Bijan, Bail Financial Sharing (BFS): A Financial Subsystem of Rastin PLS Banking. Bank Melli Iran, Tehran, Iran, 20I4. International Journal of Islamic Banking and Finance Research, 3(I), 2I-27, 2019.

https://www.cribfb.com/journal/index.php/ijibfr/article/view/266

http://www.bidabad.com/doc/bfs-paper-en.pdf

Bidabad, Bijan, Rastin Personal Security (RPS). Journal of Islamic Economics, Banking and Finance, JIEBF, Volume - II, Number - 2, April - June 20I5, pp. 47-6I.

http://www.bidabad.com/doc/rps-paper-en.pdf

http://ibtra.com/pdf/journal/vI I_n2_article3.pdf

Bidabad, Bijan, Rastin Social Takaful (RST). Journal of Islamic Economics, Banking and Finance, JIEBF, Volume - I I, Number - I, January - March 2015, pp.: I3-23.

http://www.bidabad.com/doc/rst-paper-en.pdf

http://ibtra.com/pdf/journal/vII_nI_articleI.pdf

Bidabad, Bijan, Abul Hassan, Ben Ali Mohamed Sami, Mahmoud Allahyarifard. Interest-Free Bonds and Central Banking Monetary Instruments. International Journal of Economics and Finance. Vol. 3, no. 3, August 20I I, pp.234-24I. http://www.ccsenet.org/journal/index.php/ijef/article/download/I I665/8300 
Bidabad, Bijan, M Allahyarifard, M Sherafati, Rastin Partnership Accounting Part I: General Procedure, Journal of Islamic Accounting and Business Research, 2019.

https://doi.org/IO.I I08/JIABR-04-2016-0049

\section{Copyrights}

Copyright for this article is retained by the author(s), with first publication rights granted to the journal. This is an open-access article distributed under the terms and conditions of the Creative Commons Attribution license (http://creativecommons.org/licenses/by/4.0/). 